$$
\begin{aligned}
& \begin{array}{ll}
\hline \text { 薬 } \\
\hline
\end{array} \\
& \text { アルデシン }{ }^{\circledR} \mathrm{AQ} \text { ネーザルの鼻閉に対する効果 } \\
& \text { 一小児アレルギー性鼻炎例での検討一 } \\
& \text { 山際 幹 和 }
\end{aligned}
$$

\title{
Effect of Beclomethasone Dipropionate Aqueous Nasal Spray on Nasal Obstruction in Pediatric Patients with Perennial Nasal Allergy
}

\author{
Mikikazu Yamagiwa \\ (Matsusaka Chuo Hospital)
}

The author evaluated the efficacy of beclomethasone dipropionate aqueous nasal spray (BDANS) at $300 \mu \mathrm{g} /$ day for 2 weeks, followed by $100 \mu \mathrm{g} /$ day for $1-8$ weeks, on nasal obstruction in 12 pediatric patients (9 males and 3 females, aged 6-14 years, mean age 8.8 years) with perennial nasal allergy symptoms. A $100 \mathrm{~mm}$ visual analogue scale (VAS) was used for subjective measurement of the nasal sensation of airflow, and acoustic rhinometry (AR) was used for objective measurement of the nasal cavity dimensions on entering the trial, and at 1,2 and 3-11 weeks after the start of medication.

1. The mean \pm standard error (SE) of the VAS score was $45.8 \pm 8.3$ before treatment, $14.3 \pm 4.0$ at one week, $14.0 \pm 2.8$ at two weeks, and $22.9 \pm 4.3$ at more than 3 weeks after the start of medication. The Friedman test for overall analysis showed significant variance in the VAS scores $(P=0.0070)$.

2. The mean $\pm \mathrm{SE}$ of the right+left minimum cross-sectional area of the nose (MCA) was $0.29 \pm 0.06 \mathrm{~cm}^{2}$ before treatment, $0.46 \pm 0.04 \mathrm{~cm}^{2}$ at one week, $0.45 \pm 0.04 \mathrm{~cm}^{2}$ at two weeks, and $0.44 \pm 0.05 \mathrm{~cm}^{2}$ at more than 3 weeks after the start of medication. The Friedman test showed significant variance in the MCA values $(P=0.0045)$.

3 . The mean $\pm \mathrm{SE}$ of the right + left nasal cavity volume $(\mathrm{NCV})$ was $4.50 \pm 0.46 \mathrm{~cm}^{3}$ before treatment, $5.66 \pm 0.40 \mathrm{~cm}^{3}$ at one week, $5.69 \pm 0.39 \mathrm{~cm}^{3}$ at two weeks, and $5.39 \pm 0.34 \mathrm{~cm}^{3}$ at more than 3 weeks after the start of medication. The Friedman test showed significant variance in the NCV values $(P=0.0002)$.

In conclusion, the present VAS and AR studies demonstrated that BDANS was effective in reducing allergy-induced nasal obstruction in children.

Key words : beclomethasone dipropionate aqueous nasal spray, pediatric patients, allergic nasal obstruction, visual analogue scale, acoustic rhinometry 
はじめに

プロピオン酸ベクロメタゾン (BDP) は，1964年に局 所用合成副腎皮質ホルモン剂として開発され，わが国で は，1981年にその吸入剂が承認された。本剤は，局所作 用が強いにもかかわらず，全身作用が弱いことが特徵的 であり，肺や消化管からの吸収が弱いことや吸収されて も急激に不活性化されることが知られている11.

フロンガスを使用した BDP 吸入剂は，わが国では今 日までに，成人のみならず小児アレルギー性鼻炎患者に 対してもよく用いられ，優れた効果とともに極めて安全 性も高いことが確認されている2) 4).そして，自覚的な 鼻閉塞感に対する BDP 吸入剂の効果を小児例を対象と して評価した成績をみると，改善率は72.7〜81.5\% 2) 4) に分布し, 特に, 発作期にその効果が著しいことを示す 成績が報告されている。

近年，フロンガスを使用しない BDP 定量噴射式懸濁 剤として製剤化されたアルデシン ${ }^{\circledR} \mathrm{AQ}$ ネーザルは，同 類の懸濁剂の中では小児患者に対する使用が承認されて いる製剤であり，それに対する期待は大きい，しかしな がら，この製剤の小児通年性アレルギー性鼻炎患者の鼻 閉に対する効果を検討した成績は論文報告されていない.

ところで, 難治症状である鼻閉塞を客観的に評価する ことが容易ではないことは周知の事実である．特に，一 般的に行われている鼻鏡を用いた甲介の腫脹度の視診評 価法の精度は低いと言っても過言ではない。すなわち, 自覚的鼻閉塞感と鼻鏡による甲介腫脹度評価の不一致を 示寸試験成績が得られることは珍しくない5)6).

そこで，筆者は，小児アレルギー性鼻炎患者を対象と して，アルデシン® $\mathrm{AQ}$ ネーザルを常用量および減量投 与し，その鼻閉に対する効果を，種々の感覚の測定に用 いられる visual analogue scale (VAS)7)8) と， ほぼ瞬時に 非侵襲的に鼻腔の幾何学的形態を計測できる画期的な方 法である acoustic rhinometry (AR) $)^{9)}$ を用いて検討した.

\section{研究方法}

\section{I . 試験対象例}

問診, 鼻内所見, 鼻汁好酸球検査, 血清特異的 $\operatorname{IgE}$ 抗体検査, 鼻誘発反応などで通年性アレルギー性鼻炎と 診断された外来小児患者のなかで，試験内容の十分な説 明の後に試験対象者としての同意が得られた 12 名(男児 9 名, 女览 3 名, $6 \sim 14$ 歳, 平均土標準偏差 $8.8 \pm 2.7$ 歳) を対象とした。
これらの対象例はBDP の成分に対する過敏症の既往 はなく，それにより悪化する可能性がある疾患の罹患は なく，1例 ( 6 歳男児: 喘息様気管支炎で気管支拡張剤 テオフィリンと抗アレルギー剤塩酸シプロヘプタジンが 試験開始前と期間中に断続投与されていた）を除さ試験 開始前 8 週間と期間中は抗アレルギー内服薬や点鼻薬に よる治療は行われなかった。

対象例に和けるアレルギー性鼻炎症状は $1 \sim 6$ 歳(平 均3.8歳)に発現し, 主原因抗原は全例で室内塵 (HD) と 考えられた.そして，5名でスギ花粉， 3 名でスギ十七 ノキ花粉特異的 $\operatorname{IgE}$ 抗体が陽性であった。

II. 試験期間ならびに施設

1997年 6 月より1997年 8 月の 3 力月間に，松阪中央総 合病院耳鼻咽喉科で行われた。

III. 試験薬剤，投与量ならびに期間

試験薬剤としてアルデシン ${ }^{\circledR} \mathrm{AQ}$ ネーザル(シェリン グ・プラウ株式会社，定量噴射式懸濁剤で BDPを 1 噴 射中に $50 \mu \mathrm{g}$ 含有する)を使用し, 初めの 2 週間は 1 回 に左右鼻腔に 1 噴射ずつ, 1 日 3 回 $(300 \mu \mathrm{g} /$ 日)朝, 夕, 眠前に，それ以後は，著しく重症でない限り，1日 1 回 $(100 \mu \mathrm{g} /$ 日) 眠前に 1 週間以上連日単独経鼻噴射投与す ることとした.

$N$. 鼻閉塞の評価方法

1 ）VASを用いた鼻閉塞感の自覚的評価

図 1 に示すように，用いたVAS は目盛りのない水平 な $100 \mathrm{~mm}$ の直線で，両端を短い縦線で閉じ，左端を 0 点 (閉口経両鼻孔呼吸で全く鼻閉塞感がない状態), 右端 を100点(その呼吸状態では鼻閉塞感が強く, 口呼吸をせ ざるを得ない状態) と規定した。

対象例に測定の都度 VAS の意義を十分説明し，後で 述べるARを用いた計測の直前に，VASの線上にその

\section{$100 \mathrm{~mm}$}

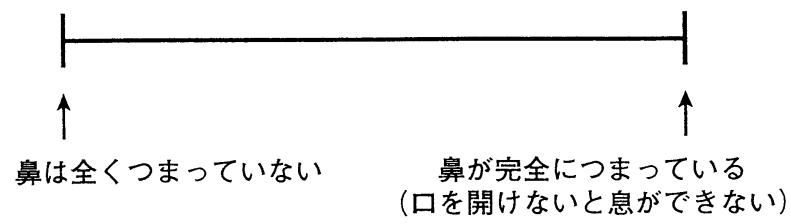

図 $1100 \mathrm{~mm}$ 水平 VAS を用いた自覚的鼻閉塞感の測定 VAS の左端(鼻は全くつまっていない)より被検者が印 した個所までの距離を測定し， $1 \mathrm{~mm}=1$ 点として点数 化した. 
時点の鼻閉塞感の強さを印させた。そして，VASの左 端よりその印までの距離を $\mathrm{mm}$ 単位で計測し， $1 \mathrm{~mm}=$ 1 点としてVAS-鼻閉塞感得点を求めた. したがって, VAS-鼻閉塞感得点は， $0 \sim 100$ 点に分布し，大きいほど 鼻閉塞感が強いことを意味する。

2) AR による鼻腔幾何学的形態の他覚的評価

図 2 は ARのブロック図を示す。音発生装置で発せ られた音波が wave tube と個々の被検者の前鼻孔の大 きさによって選択装着されるノーズピースを介して前鼻 孔に射入されると，その音波の一部は鼻腔各所の音響イ ンピーダンスの变化にともなって鼻腔外一反射されてく る. その入射波と反射波を時間的，空間的にマイクロフ オンを介して捉えてコンピューターで解析することによ り, 前鼻腔より鼻腔各所までの距離とその部の断面積を 求めることができ(図 3 ), 積分することにより任意の範 囲の鼻腔容積を求めることができる ${ }^{9}$.

AR に用いた装置はデンマークの Aarhus 大学環境職 業医学研究所で成人用として作製されたもので，主たる 部品は GJ Elektronik (Skanderborg，デンマーク)製で あり，データの収集と保存のためにコンピュータープロ グラムNADAPを用いた。この装置の詳細に関しては, 最近の同研究所よりの論文に記述されている装置 ${ }^{10)}$ と

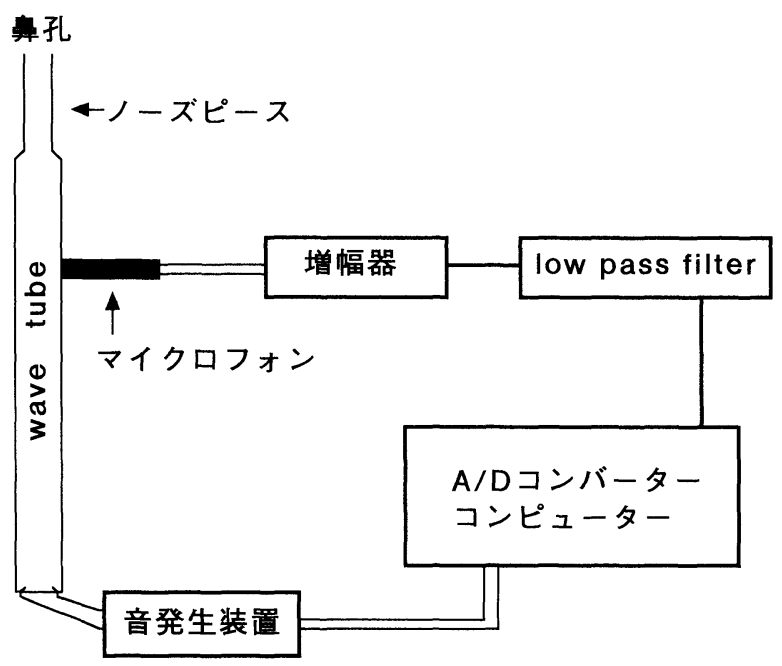

図 $2 \mathrm{AR}$ 装置のブロック図 音発生装置で発せられた音波は wave tube とノーズピー スを経由して鼻腔に射入されると，音響インピーダンス の変化にともなって反射されてくる．入射波と反射波を マイクロフォンで捉えてコンピューター解析することに より, 鼻腔の断面積一距離曲線を描くことができる.

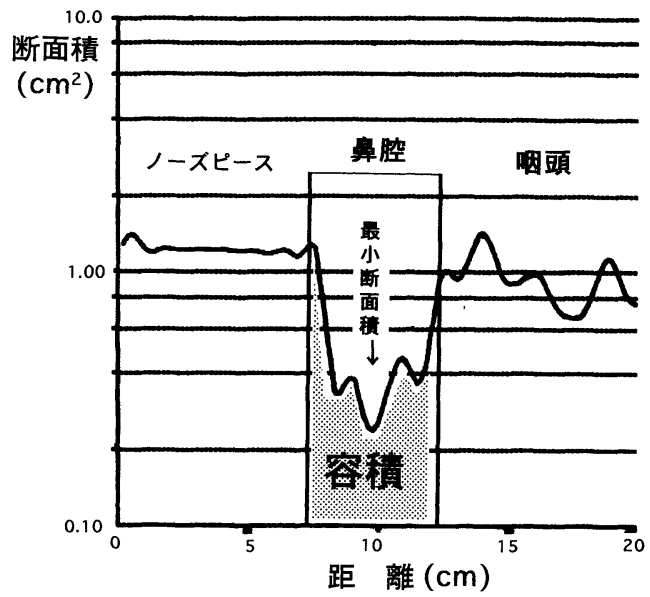

図 $3 \mathrm{AR}$ で得られた鼻腔断面積一距離曲線

6 歳, 女児 (通年性アレルギー性鼻炎, 身長 $112 \mathrm{~cm}$, 体 重 $19 \mathrm{~kg}$ )の右側鼻腔での測定成績. 最小断面積はノー ズピースの先端より $2.83 \mathrm{~cm}$ 奥に位置し, $0.24 \mathrm{~cm}^{2}$. 鼻 腔長は $4.0 \mathrm{~cm}$ で容積は $2.2 \mathrm{~cm}^{3}$.

大同小異であるのでそれにゆずる。

対象例の前鼻孔の大きさによって選択されるノーズ ピースは $100 \times 15 \mathrm{~mm}$ の Sarstedt 試験管(No 55.466, ドイッ)を加工したもので, 前鼻孔側の内径が $8 \sim 9 \mathrm{~mm}$ のものを用い，同一対象例には同一サイズのものを使用 した.

計測は右鼻から左鼻の順に各側連続 3 回ずつ施行し, 各側とも重ね描きした 3 本の断面積一距離曲線が注湆重 複し，ノーズピース部により形成される基線が水平で, 鼻入口部での音漏れを示唆する異常上昇やノーズピース の挿入角度が不適切であるときに生じる異常低下がない ことを確認したうえで, それらの平均曲線と偏差を示す 曲線を資料として採用し，ディスクに記録保存した。

解析は平均曲線を資料として行い，客観的鼻閉塞のパ ラメーターとして, 右十左最小鼻腔断面積と右十左鼻腔 容積を演算プログラム $(\mathrm{RHINO})$ を用いて算出した。鼻 腔容積の計算に際しては, 頭部側面単純X線写真上で前 鼻棘 (anterior nasal spine) の先端と上顎洞低部後壁まで の距離を計測して求めた值を鼻腔長として採用した。

VI. 対象例の選択と鼻閉塞の評価時期

試験開始日 $(0$ 週目)には, まず, 無処置の状態で VAS とARによる鼻閉塞の評価を行い,つぎに, 点鼻 用血管収縮剂塩酸トラマゾリンを左右鼻腔に $0.1 \sim 0.2$ $\mathrm{ml}$ ずつ噴霧し，10３0分経た時点で同様の評価を行っ 
た．対象とした12例では，血管収縮剤点鼻後に AR で 右十左最小鼻腔断面積と右十左鼻腔容積の増加が認めら れ, かつ, VAS の得点の軽減 (鼻閉塞感の自覚的軽減) が認められた。このことから，これらの例は，VASの 機能を十分理解できた例であると評価し, 試験対象例と して採択した.

投薬(300 $\mu \mathrm{g} /$ 日) は対象観察期間を括かずに試験開始 日に開始し，投薬開始後 1 週目と 2 週目にVAS と AR による評価を行った． 2 週目で著しく重症であった例は なかったので, 以後は減量 $(100 \mu \mathrm{g} /$ 日) 投与し, 減量投 与開始後 1 週目以後 $(1 \sim 8$ 週目, 平均 2.4 週目 $)$ に VAS とARによる最終評価を行った。

VII. 推計学的検討

推計学的検討は, ノンパラメトリックテストである Friedman の検定を行い，投薬により測定值の有意 $(P<$ 0.05)の変動が示された場合には, Wilcoxon の符号順 位検定を準用して治療開始前值と治療中の值との群間比 較を行った.

\section{結 果}

1 ）治療効果判定に影響を与える事項

試験期間内に重複抗原としての花粉の飛散はなく，問 診からは，全例で効果判定に著しい影響を与えるよらな 特別な事項(急性上気道炎罹患, 試験薬の非使用, 試験 に影響を与える点鼻薬の併用など)は生じてなく，予定 した時期に鼻閉に対する効果の評価が実施された。

2) VAS で評価した自覚的鼻閉塞感に対するアルデ シン ${ }^{\circledR} \mathrm{AQ}$ ネーザルの効果(図 4)

VAS-鼻閉塞感得点は，投薬開始前では $17 \sim 100$ 点に分 布し，その平均土標準誤差は45.8 8 8. 点であった。 そ れらは，投薬開始後 1 週目には $0 \sim 52$ 点, $14.3 \pm 4.0$ 点(平 均 $61.8 \%$ 減)， 2 週目には $0 \sim 27$ 点， $14.0 \pm 2.8$ 点 (平均 62.8\%減) と顕著に減少した。減量投与後のそれらは 0 $\sim 46$ 点, $22.9 \pm 4.3$ 点 (平均 $36.7 \%$ 減) で若干の反跳が観 察された。

ちなみに，血管収縮剤点鼻後のそれらの值は 0 ３6点 と $16.3 \pm 3.1$ 点(平均 $64.9 \%$ 減)であった.

Friedman の検定で，投薬開始後に測定値が有意に変 動したことが示され $(P=0.0070)$, Wilcoxon 符号順位検 定を準用すると，投薬開始前値と 1 週目 $(P=0.0047)$, 2 週目 $(P=0.0032)$ 抢よび減量投与後 $(P=0.0229)$ の值 の間には有意差があった。
3) AR で評価した右十左最小鼻腔断面積に対するア ルデシン ${ }^{\circledR} \mathrm{AQ}$ ネーザルの効果(図 5 )

右十左最小鼻腔断面積は，投薬開始前では $0 \sim 0.66$ $\mathrm{cm}^{2}$ 亿分布し, その平均土標準誤差は $0.29 \pm 0.06 \mathrm{~cm}^{2}$ であった。それらは，投薬開始後 1 週目には $0.21 \sim$ $0.71 \mathrm{~cm}^{2}$ と $0.46 \pm 0.04 \mathrm{~cm}^{2}$ そ増加し, 完全鼻腔閉塞を 認めた 1 例 ( 9 歳, 男児)を除いた11例で求めた増加率の 平均は $193.3 \%$ であった。 2 週目のそれらは $0.33 \sim 0.76$ $\mathrm{cm}^{2}$ と $0.45 \pm 0.04 \mathrm{~cm}^{2}$ で, 増加率の平均は $184.9 \%$ であ った. 減量投与後のそれらは $0.12 \sim 0.73 \mathrm{~cm}^{2}$ と $0.44 \pm$ $0.05 \mathrm{~cm}^{2}$ で, 増加率の平均は103.5\%であった。

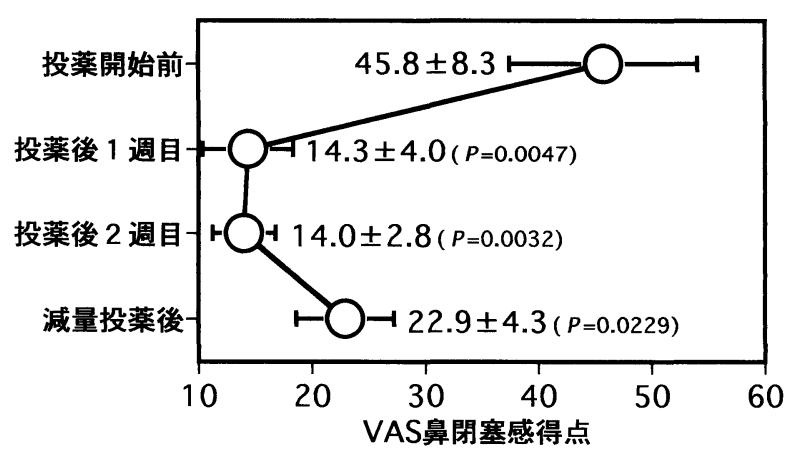

図4 アルデシン ${ }^{\circledR} \mathrm{AQ}$ ネーザル投薬前後での VAS-鼻閉塞感 得点の推移

Friedman の検定で, 投薬開始後に測定值が有意に変動 したことが示された $(P=0.0070)$. 本図ならびに図 5 ， 図 6 中の数值は平均土標準誤差を表し，各 $P$ 值は投薬 開始前值との間で Wilcoxon 符号順位検定を行って求め た。

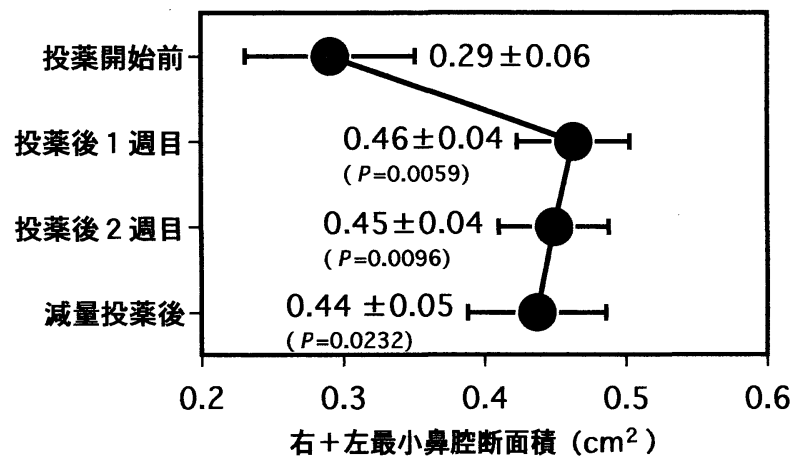

図 5 アルデシン ${ }^{\circledR} \mathrm{AQ}$ ネーザル投薬前後での右十左最小鼻腔 断面積の推移

Friedman の検定で，投薬開始後に測定值が有意に変動 したことが示された $(P=0.0045)$. 
ちなみに，血管収縮剤点鼻後のそれらの值は $0.16 〜$ $0.93 \mathrm{~cm}^{2}$ と $0.52 \pm 0.06 \mathrm{~cm}^{2}$, 増加率の平均は $146.1 \%$ で あった。

Friedman の検定で投薬開始後に測定值が有意に変動 したことが示された $(P=0.0045)$. Wilcoxon 符号順位検 定を準用すると，投薬開始前值と 1 週目 $(P=0.0059)$, 2 週目 $(P=0.0096)$ 特よび減量投与後 $(P=0.0232)$ の值 の間には有意差があった。

4) AR で評価した右十左鼻腔容積に対するアルデシ ン ${ }^{\circledR} \mathrm{AQ}$ ネーザルの効果(図 6 )

$\mathrm{X}$ 線写真上で計測した鼻腔長の值は 40〜 $51 \mathrm{~mm}$ に分 布し；その平均士標準偏差は $47.3 \pm 3.2 \mathrm{~mm}$ であった.

これらの鼻腔長を適用して求めた右十左鼻腔容積は投 薬開始前では $2.48 \sim 7.93 \mathrm{~cm}^{3}$ に分布し，その平均土標 準誤差は $4.50 \pm 0.46 \mathrm{~cm}^{3}$ であった。それらは，投薬後 1 週目には $4.40 \sim 9.02 \mathrm{~cm}^{3}$ と $5.66 \pm 0.40 \mathrm{~cm}^{3}$ に増加し, 増加率の平均は $32.8 \%$ であった。 そして，2 週目のそれ らは 4.16 9.02 $\mathrm{cm}^{3}$ と $5.69 \pm 0.39 \mathrm{~cm}^{3}$ で, 増加率の平 均は $34.5 \%$ であった。減量投与後のそれらは 4.32 $7.84 \mathrm{~cm}^{3}$ と $5.39 \pm 0.34 \mathrm{~cm}^{3}$ で, 増加率の平均は $27.3 \%$ であった。

ちなみに，血管収縮剤点鼻後のそれらの值は 4.56〜 $10.13 \mathrm{~cm}^{3}$ と $6.52 \pm 0.52 \mathrm{~cm}^{3}$ で, 増加率の平均は 50.1 \%であった。

Friedman の検定で投薬開始後に測定值が有意に変動 したことが示され $(P=0.0002)$, Wilcoxon 符号順位検定 を準用すると，投薬開始前値と 1 週目 $(P=0.0022), 2$ 週目 $(P=0.0022)$ および減量投与後 $(P=0.0150)$ の値の

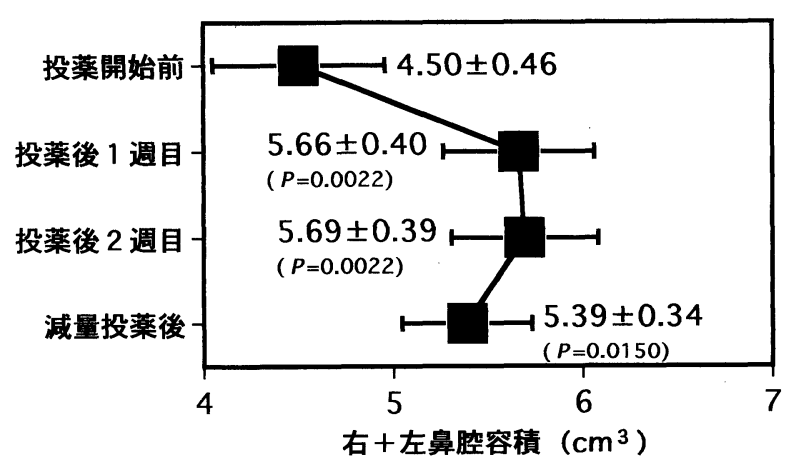

図 6 アルデシン ${ }^{\circledR} \mathrm{AQ}$ ネーザル投薬前後での右十左鼻腔容積 の推移

Friedman の検定で，投薬開始後に測定值が有意に変動 したことが示された $(P=0.0002)$.
間には有意差があった。

5 ）アルデシン ${ }^{\circledR} \mathrm{AQ}$ ネーザールの鼻閉塞に対する有 効性の客観的評価

AR で測定した右十左最小鼻腔断面積と右十左鼻腔容 積の双方とも $15 \%$ 以上増加した場合を客観的に有効と定

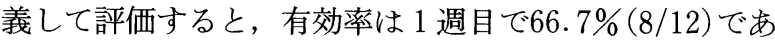
り，有効例中の $75.0 \%(6 / 8)$ で VAS-鼻閉塞感得点が 50 $\%$ 以上減少した。 2 週目と 3 週目の有効率はともに 50.0 $\%(6 / 12)$ で，有効例中で VAS-鼻閉塞感得点が50\%以上 減少した比率はいずれも $83.3 \%(5 / 6)$ であった。

6 ）アルデシン ${ }^{\circledR} \mathrm{AQ}$ ネーザルによる有害事象

今回の対象例の中で, 試験期間中にアルデシン视 $\mathrm{AQ}$ ネーザルによると考えられる有害事象を呈した例はなか った。

7 ）代表的症例

症例 : 9 歳, 男児.

試験開始：1997年 7 月 24 日.

家族歴：父方の祖父が気管支喘息，父がアトピー性皮 膚炎，母がスギ花粉症.

既往歷：特記すべきものなし.

現病歴 : 身長 $138 \mathrm{~cm}$, 体重 $28 \mathrm{~kg}$, 最近の 2 年間, 通 年性に鼻閉, 鼻汁, 鼻の痒みなどのアレルギー性鼻炎症 状があり受診した。

現症：鼻粘膜は著しく腫脹し中甲介は見えず，色調は 蒼白で，中等量の水溶性鼻汁がみられた。鼻汁の検鏡で は, 弱拡大で好酸球が散見された。 X線検査上, 感染性 副鼻腔炎の合併はなく，鼻腔長は $46 \mathrm{~mm}$ であった。

血清総 IgE 值は $49 \mathrm{U} / \mathrm{ml}$ であったが, AlaSTAT 特 異的血清 $\mathrm{IgE}$ 抗体検査では，HD6 がクラス 4 (24.6 $\mathrm{IU} / \mathrm{ml})$, スギ花粉がクラス $3(6.92 \mathrm{IU} / \mathrm{ml})$ で陽性であ った。

臨床経過：図 7 は治療経過中に得られたAR 鼻腔断 面積一距離曲線を, また, 図 8 は鼻閉塞の各パラメーター の推移を示す。試験開始日（週 0 )の基準値の測定では, VAS-鼻閉塞感得点 100 点, 右十左最小鼻腔断面積 0.00 $\mathrm{cm}^{2}$, 右十左鼻腔容積 $2.62 \mathrm{~cm}^{3}$ で, 自覚的のみならず 客観的にも鼻腔は完全に閉塞していると考元られ，その 日の夕食後よりアルデシン裤 $\mathrm{AQ}$ ネーザル $(300 \mu \mathrm{g} /$ 日) の投与を開始した。

投薬開始後 1 週目では, VAS-鼻閉塞感得点は顕著に 減少し(20点), 右十左最小鼻腔断面積 $\left(0.43 \mathrm{~cm}^{2}\right)$ と右 十左鼻腔容積 $\left(5.30 \mathrm{~cm}^{3}\right)$ も著しく増加した. 

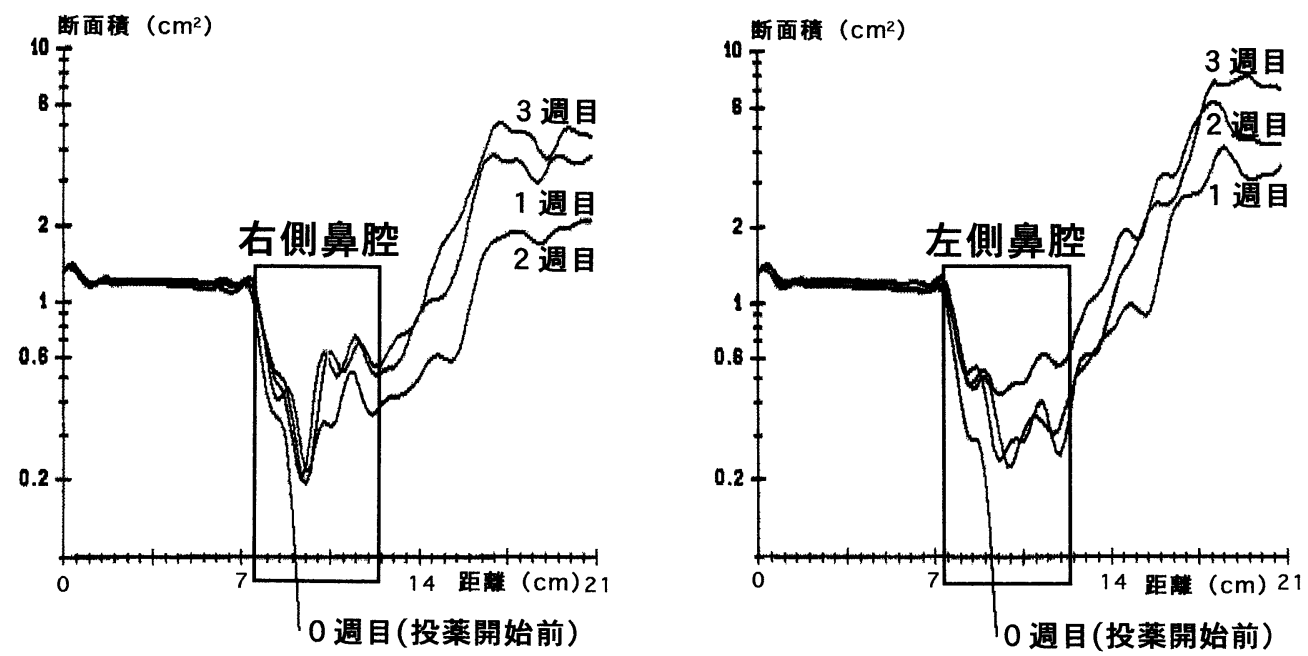

図 7 アルデシン ${ }^{\circledR} \mathrm{AQ}$ ネーザル投薬前後での右左鼻腔の $\mathrm{AR}$ 断面積一距離曲線の推移

9 歳, 男児(通年性アレルギー性鼻炎, 身長 $138 \mathrm{~cm}$, 体重 $28 \mathrm{~kg}$ )。アルデシン ${ }^{\circledR} \mathrm{AQ}$ ネー ザル投薬開始前 $(0$ 週目) には scale out (鼻腔完全閉塞) であったが，開始後 1 週目以後は 顕著に鼻腔が開大した. nasal cycle の影響で 2 週目の曲線(相対的に右側閉，左側開) は 1,3 週目のそれらと異なっている.
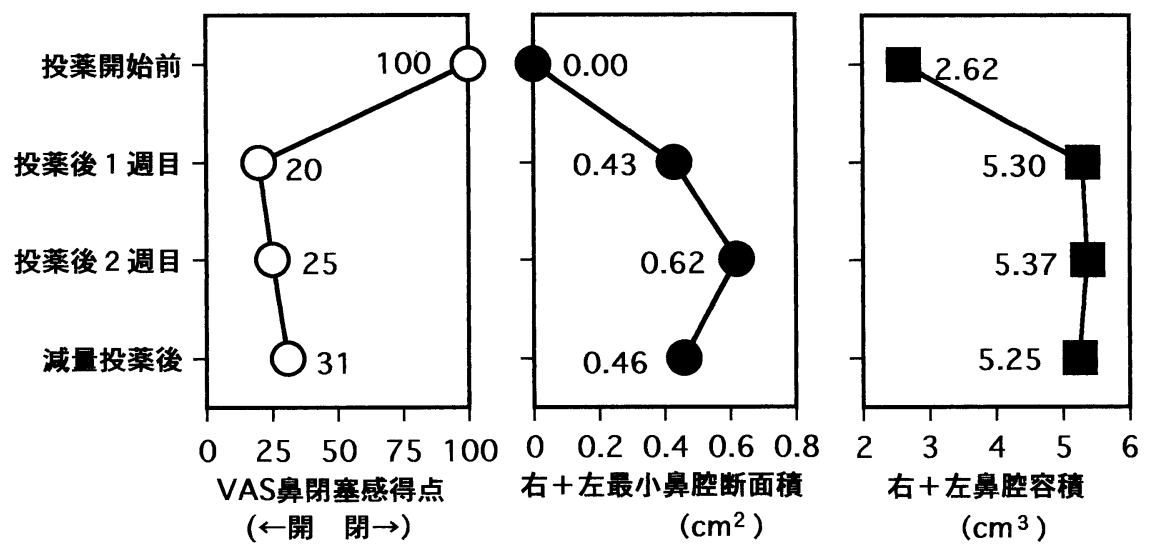

図 8 アルデシン ${ }^{\circledR} \mathrm{AQ}$ ネーザル投薬前後での VAS-鼻閉塞感得点, 右十左最小鼻腔 断面積, 右十左鼻腔容積の推移

図 7 脚注に略述した症例. 投薬開始前後の各測定値は互いに矛盾することな く推移し，総括評価すると，投薬開始後 1 週以内に最大の効果が得られてい ると考えられる.

投薬開始後 2 週目で, 右十左最小鼻腔断面積はさらに 増加したが $\left(0.62 \mathrm{~cm}^{2}\right)$ ， その他の值 $\left(25\right.$ 点， $\left.5.37 \mathrm{~cm}^{3}\right)$ は 1 週目の値と近似しており, 投薬開始後 1 週以内に最大 の効果が得られたことが示唆された.

そして，減量投与 $(100 \mu \mathrm{g} /$ 日) 開始後 1 週目でも十分 な鼻腔開存状態 $\left(31\right.$ 点, $\left.0.46 \mathrm{~cm}^{2}, 5.25 \mathrm{~cm}^{3}\right)$ が存続して

\section{いることが示された.}

な拈，血管収縮剂点鼻後のそれらの值は，33点， 0.48 $\mathrm{cm}^{2}, \quad 5.31 \mathrm{~cm}^{3}$ であり，アルデシン ${ }^{\circledR} \mathrm{AQ}$ ネーザルの投 与で得られた開鼻効果はこれに匹敵するものであった。

この例では, VAS-鼻閉塞感得点が右十左最小鼻腔断 面積と右十左鼻腔容積の双方と極めて強く相関し(図 

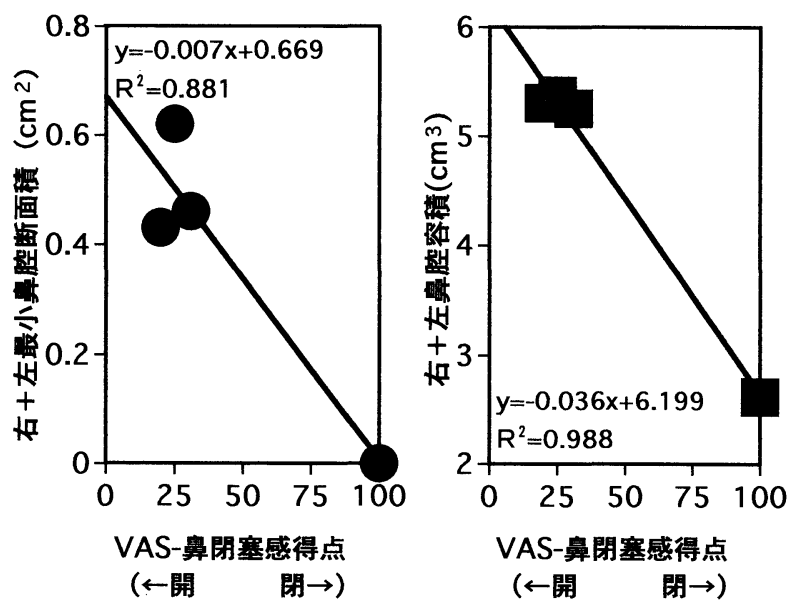

図 9 同一症例内での VAS-鼻閉塞感得点と AR 測定值(右+ 左最小鼻腔断面積, 右十左鼻腔容積)の相関 図 7 脚注に略述した症例. 図中の線形方程式と相関係数 $\left(R^{2}\right)$ が示すように, VAS-鼻閉塞感得点と AR 測定值の 相関は極めて強い。

9 )，線形方程式は以下のようになった.

右 + 左最小鼻腔断面積 $\left(\mathrm{cm}^{2}\right)=-0.007 \times \mathrm{VAS}-$ 鼻閉塞 感得点 +0.669 , 相関係数 $\left(R^{2}\right)=0.881$

右十左鼻腔容積 $\left(\mathrm{cm}^{3}\right)=-0.036 \times \mathrm{VAS}-$ 鼻閉塞感得点 $+6.199, \quad \mathrm{R}^{2}=0.988$

\section{考察}

アレルギー性鼻炎の薬物治療を行ららえで, 注とんど 問題となる副作用を有せず著しい薬効を発揮する局所用 副腎皮質ステロイド阂1112) は必要不可欠の薬剤である と言っても過言ではない. 小児アレルギー性鼻炎患者の 治療に際しても, それは重要な役割を担って括り, 速効 的でその安全性は高いとされている。例えば, Kokron ら 13) は, 小児アレルギー性鼻炎患者に対して 4 週間に わたって BDPを 1 日 $400 \mu \mathrm{g}$ あるいは $800 \mu \mathrm{g}$ 鼻腔内投 与し，その視床下部一下垂体一副腎系に対する抑制作用を 調査したところ，プレドニゾロン $(1 \mathrm{mg} / \mathrm{kg} /$ 日)を 2 週 間全身投与した後に生じたよらな抑制がみられないこと を観察し，小児患者に対してもBDP 吸入剂が十分安全 性の高い薬剤であることの一端を証明した。そのような 安全性に関する報告がある一方で, 治療者側には, な拉 全身的な副作用に対する懸念もあり, 特に小児患者に対 してはより効果の低い他の治療が選択されるきらいがあ り，局所用副腎皮質ステロイド斉の使用頻度は予想以上
に低いことが指摘されている14).

わが国で論文発表された小児アレルギー性鼻炎患者に 対する BDP 吸入剂の効果の検討を目的とした臨床試験 の成績をみると 2) 4)，BDP の投与量は 1 回 $100 \mu \mathrm{g}$ を 1 日 2 ないし 3 回 (総量 $200 \sim 300 \mu \mathrm{g}$ ) 投与した場合が多い. その際の，自覚症状の改善率は，〈しゃみ68.2〜 90.9\%, 鼻汁63.6〜 75.5\%，そして，前述のように鼻閉72.7〜 $81.5 \%$ である ${ }^{2)}$. . アルデシン ${ }^{\circledR} \mathrm{AQ}$ ネーザルもこの投 与量で同様の効果を発揮するはずであり, 輸入・発売会 社の資料には，小児の常用量は $200 \mu \mathrm{g} /$ 日で最大投与量 は $400 \mu \mathrm{g} /$ 日と記載されている15).

今回の臨床試験は, 医の倫理上問題がないとは言えな い無投薬での観察期間を設けずに実施した。試験開始日 よりアルデシン® $\mathrm{AQ}$ ネーザル $300 \mu \mathrm{g} /$ 日による 2 週間 の導入治療を開始し, 続いて, 一応の効果が期待できる $100 \mu \mathrm{g} /$ 日 $^{16)}$ に減量投与し, その際の自他覚的抗鼻閉効 果を検討した.

その結果, アルデシン® $\mathrm{AQ}$ ネーザルの抗鼻閉効果は, いずれの投与量の際にも明白であり，推計学的にも VAS で測定した鼻閉塞感得点とAR で計測した右十左 最小鼻腔断面積と右十左鼻腔容積が有意に変動したこと が確認された.

ところで，小児の鼻閉塞を測定するらえで，果たして VAS や AR が精度の高い方法であるのか否かの問題が ある、筆者は, 今までに行った76名の小児アレルギー性 または感染性鼻 ・ 副鼻腔炎患者 $(4.9 \sim 12.5$ 歳, 平均士標 準偏差 $8.7 \pm 2.0$ 歳)を対象とした検討で，成人用 $\mathrm{AR}$ 装 置はこの年齢層の小児に拈いても精度の高い測定装置で あると考えるに至っている17)。ひとつには, 今回も鼻閉 塞のパラメーターのひとつとして採用した右十左鼻腔容 積はそれらの76例では 3.2 14.0 $\mathrm{cm}^{3}$ に分布し, その平 均士標準偏差は $5.8 \pm 1.7 \mathrm{~cm}^{3}$ であり ${ }^{17}$ ), 健常成人 (平均 土標準偏差 : $13.3 \pm 3.2 \mathrm{~cm}^{3}$ ) ${ }^{18)}$ と健常乳幼児 (小児用に 改良された $\mathrm{AR}$ 装置による測定で, 平均士標準偏差 $\left.1.84 \pm 0.34 \mathrm{~cm}^{3} \sim 2.37 \pm 0.56 \mathrm{~cm}^{3}\right)^{19) \sim 21)}$ より得られた值 の中間に位置し，不自然な值ではなかった。ささらにそそ の年齢層 $(4.9 \sim 12.5$ 歳)では, 右十左鼻腔容積と年齢と の間にかなりの相関 (右十左鼻腔容積 $\left(\mathrm{cm}^{3}\right)=0.353 \times$ 年 齢 +2.744 , 相関係数 $(\mathrm{R})=0.413)$ が示されたこともとの AR 装置の精度の高さを裏付けている ${ }^{17)}$.

今回対象とした 12 例の治療前の右 + 左鼻腔容積は $2.48 \sim 7.93 \mathrm{~cm}^{3}$ に分布し, その平均土標準誤差は 4.50 
$\pm 0.46 \mathrm{~cm}^{3}$ であり, 前出の76例で得られた值に近く, 筆者らが検討したアレルギー性鼻炎成人例22 25) のそれ が，対象とした集団による若干の差はあったものの， $12.1 \pm 0.8 \sim 13.8 \pm 1.4 \mathrm{~cm}^{3}$ の範囲にあった点とは大き く異なっていた．したがって，今回の検討では，成人用 $\mathrm{AR}$ 装置が用いられたが，得られた測定值は実際の鼻腔 断面積や鼻腔容積と大きくかけ離れたものではないと推 察され，少なくとも，治療前後のとれらの相対的な变化 を十分捉えることができたと言える.

他方, VAS-鼻閉塞感得点の持つ意味は, 成人でも小 児でも，個体間でかなり異なり，ばらつきが大きい。す なわち，筆者の経験では，ある例の示す100点(両鼻腔完 全閉塞) と別の例の 100 点は大差がないと思われるが，そ の他の得点, 例光ば45点を例にとると, その意味する鼻 閉塞感は個体間でかなり異なっている，そして，成人で も ${ }^{26)}$ 小児でも ${ }^{17)}$, 集団として検討した場合には，VAS鼻閉塞感得点は右十左最小鼻腔断面積と右十左鼻腔容積 のいずれとも相関しない．しかしながら，同一個体内で 反復測定した成績を検討すると, 今回の代表的症例でも 示されたように(図 9), 成人 ${ }^{26)}$ 小児 ${ }^{17)}$ そかかわらず, 多くの例でVAS-鼻閉塞感得点と右十左最小鼻腔断面積 や右十左鼻空容積は強く相関する．したがって，個々の 例は，独自の目盛りを持ったVASを用いて自身の鼻閉 塞状態を測定していると言える。このことは，今回のよ らにVAS-鼻閉塞感得点を用いて同一患者群内での自覚 的な鼻閉塞感の変動を評価しても問題がないことを示唆 しているが，VAS-鼻閉塞感得点を群間で比較し鼻閉塞 状態の程度の大小に言及することはでさない．

成人のみならず27，小児に执いてもアレルギー性鼻炎 患者の自覚症状の解析から, 局所用副腎皮質ステロイド 剤は鼻閉塞感に対して速効性を有することが指摘されて いる3．今回の成績は，確かにアルデシン® $\mathrm{AQ}$ ネーザ ルも小児アレルギー性鼻炎患者に対して速効性を有し， 投薬後 1 週間以内に注湆最大に近い効果が得られること を客観的に示している.さらに，局所用副腎皮質ステロ イド剤一般にあてはまる長所として, 抗鼻閉塞感効果が 長期に続く点があり 27)，小児患者でも，BDP吸入剂の 効果は投薬終了後少なくとも 1 ～週間は持続すること を示す成績が発表されている314).今回，筆者はとの点 を検討しえなかったが，アルデシン ${ }^{\circledR} \mathrm{AQ}$ ネーザルを 2 週間常用量投与した後で減量投与する方法は，十分満足 すべき効果を持続させることができる治療方法であるこ
とを客観的に示すことができた. したがって，頻回の受 診が困難な例に対しては断続投与のみならず減量投与も 一考值する。

鼻腔通気度検查は沉用されてきた他覚的検査法である が, 測定に比較的時間を要し, 検者と被検者双方の十分 な訓練を経て，信頼できるデータを提供するものであり， 日常臨床レベルでは小児に用いがたいのが実状である28). 他方，筆者がここで客観的方法として用いた ARは， 外来診療のなかで短時間内に容易に実施でき, 小児患者 でも, 鼻閉塞に対する薬剤の効果を文字ど括り客観的に 評価するら兊で極めて有用でめり, 右十左最小鼻腔断面 積や右十左鼻腔容積の計測成績は自覚的評価法として用 いたVASによる測定成績と矛盾することはなかった。 このことより，成人患者に対して行ってきたARと VAS を組み合わせて評価する方法 $\left.{ }^{22} \sim 25\right)$ は自他覚的に 小児患者の鼻閉塞に対する薬効を評価する方法としても 極めて有用性が高いと考光る.

アレルギー性鼻炎に用いる各種の薬剂の抗鼻閉効果の 大小を比較する方法はまだ確立されていないが，ARに よって求め得る治療後の右十左最小鼻腔断面積や右十左 鼻腔容積の増加率は, 成人だけではなく22) 25), 小児で も薬効の強さを比較するら兄での重要な資料になる可能 性が大きいと考光る，われわれが，成人アレルギー性鼻 炎患者を治療して得た右十左最小鼻腔断面積の最大の効 果が得られたときの平均増加率は $39 \%$ であり, 右十左鼻 腔容積のそれは24\%であった22 25). 他方, 今回の小児 患者の中には, 鼻腔が完全閉塞あるいは高度に閉塞して いた例が含まれていたこともあり，右十左最小鼻腔断面 積のその率を計算すると $193.3 \%$ (投薬開始後 1 週目で - 13.6\%～無限大に分布)で, 異常に高い值になった. それに対して, 右十左鼻腔容積のそれは34.5\%(同 2 週 目で6.6 105.0\%に分布)であり, 成人のそれに近似し, 比較的安定した值をとった22 25). 今回採用したように, 小児患者に扣いても, 右十左最小鼻腔断面積と右十左鼻 腔容積の双方の増加率は客観的に薬効を評価する際の指 標となりらるが，それらがどの程度増加した場合を有効 とするかの問題があり, それは今後の検討課題である. ここでは, 右十左最小鼻腔断面積と右十左鼻腔容積のい ずれもが15\%以上増加した場合を有効と仮定したところ， 有効例の $75 \%$ 以上で自覚的な満足感 (VAS-鼻閉塞感得点 が50\%以下に減少)が得られている. 治療後の右十左鼻 腔容積の増加率は, 成人例でも ${ }^{22) ~ 25)}$ 今回の小児例でも 
值のばらつきが比較的小さく，今回の成績をみると，そ れが $15 \%$ 以上増加した例の $83.3 \%$ 以上でVAS-鼻閉塞感 得点が $50 \%$ 以上減少していた. な和検討の余地はあるが， 右十左鼻腔容積の増加率のみを評価の対象としても不都 合はないかとも考える.

また，成人患者では，血管収縮剤を十分な量点鼻する と, 再現性の高いほぼ最大に近い開鼻効果が得られるこ とから，その効果を対照として試験薬剂の効果を評価す ることも可能である ${ }^{22 \sim 250}$. ᄂかしながら，今回の検討 結果からもらかがわれるように，特に低年齢の小児患者 に怙ける血管収縮剤点鼻液の開鼻効果は成人患者の場合 と異なって 22レ 25) 顕著ではない17)。したがって，小児患 者においても血管収縮剤の点鼻で対照としらる鼻腔の最 大に近い開存状態，言い替光れば，鼻腔の枠組みの大き さを推測し得る開存状態が高い再現性をもって得られる か否かは不明であり，この状態を対照とすることには多 少の疑問がある.

結論として，今回の VAS とARを用いた臨床試験成 績は，アルデシン® $\mathrm{AQ}$ ネーザルが，小児通年性アレル ギー性鼻炎患者の鼻閉塞に対して有用であることを示す ものである.

\section{まとめ}

小览通年性アレルギー性鼻炎患者 12 名 $(6 \sim 14$ 歳, 平 均8.8歳)をアルデシン® $\mathrm{AQ}$ ネーザルで治療し, visual analogue scale (VAS) と acoustic rhinometry (AR)によ る鼻閉塞の自他覚的評価を行った.

その結果, VAS による鼻閉塞感の軽減，ARによる 右 + 左最小鼻腔断面積と右十左鼻腔容積の増加が投薬開 始後に認められ, Friedmanの検定でいずれの測定值も 有意 $(P<0.01)$ 飞变動したことが示された. な拉，有害 事象を呈した例はなかった。

以上より，アルデシン® $\mathrm{AQ}$ ネーザルが小児通年性ア レルギー性鼻炎患者の鼻閉塞に対して有用であることが 自他覚的検查法で示されたと考える.

\section{参考文献}

1) Harris DM : Some properties of beclomethasone dipropionate and related steroids in man. Postgrad Med J 51 Suppl $4: 20 \sim 25,1975$.

2 ) 島田均, 吉田博一, 佐藤成彦, 他: 小児鼻アレルギーに 対するアルデシンミ二鼻用の臨床的検討.薬理と治療 18 :
4729 4735, 1990.

3）稲葉 博, 永倉俊和, 飯倉洋治, 他: 小児鼻アレルギーと 対するベクロメタゾン噴霧剤 (Aldecin Nasal) の臨床的効 果. 診と薬 $16: 2915 \sim 2934,1979$.

4）荒木昭夫, 古賀慶次郎, 川城信子 : 小児鼻アレルギーに対 寸る鼻用 Beclomethasone dipropionate の使用経験. 耳展 23 補 $3: 209 \sim 216,1980$.

5 ）馬場駿吉, 高坂知節, 稲村直樹, 他 : 小青竜湯の通年性鼻 アレルギーに対する効果 一二重盲検比較試験一. 耳鼻臨 床 $88: 389 \sim 405,1995$.

6）奥田 稔, 形浦昭克, 朝倉光司, 他 : 通年性アレルギー性 鼻炎に対するフマル酸エメダスチン (KG-2413) の臨床評価 一二重盲検群間比較試験一. 耳展 33 補 $4: 543 \sim 565,1990$.

7) McCormack HM, Horne DJdeL and Sheather S : Clinical applications of visual analogue scales; a critical review. Psycol Med 18 : 1007 1019, 1988.

8 ) Linder A : Symptom scores as measures of the severity of rhinitis. Clin Allergy $18: 29 \sim 37,1988$.

9) Hilberg O, Jackson AC, Swift DL, et al : Acoustic rhinometry; evaluation of nasal cavity geometry by acoustic reflection. J Appl Physiol 66 : 295 303, 1989.

10) Lundqvist GR, Pedersen OF, Hilberg $O$, et al : Nasal reaction to changes in whole body temperature. Acta Otlaryngol (Stockh) 113 : 783 788, 1993.

11) Mygind $N$ : Topical steroid treatment for allergic rhinitis and allied conditions. Clin Otolaryngol $7: 343 \sim 352,1982$.

12) Siegel SC : Topical intranasal corticosteroid therapy in rhinitis. J Allergy Clin Immunol 81 : 985 991, 1988.

13) Kokron CM, Castro AS, Sole D, et al : Lysine-vasopres$\sin$ in the evaluation of the hypothalamic-pituitary-adrenal axis in children with allergic rhinitis treated with intranasal beclomethasone dipropionate or oral predonisone. J Investig Allergol Clin Immunol 7 : 51 56, 1997.

14) Edwards TB : Effectiveness and safety of beclomethasone dipropionate, an intranasal corticosteroid, in the treatment of patients with allergic rhinitis. Clin Ther $17: 1032 \sim 1041$, 1995.

15）シェリング・プラウ株式会社 : 医薬品インタビューフォー ム 吸入式鼻過敏症治療剂アルデシン ${ }^{\circledR} \mathrm{AQ}$ ネーザル。 9 頁, シェリング・プラウ株式会社, 大阪, 1995.

16) Shore SC and Weinberg EG:Beclomethasone dipropionate aerosol in treatment of perennial allergic rhinitis in children. Arch Dis Child 52 : 486 488, 1977.

17) Yamagiwa $M$ : Visual analogue rating and acoustic rhinometry in the evaluation of nasal obstruction in children. Proceedings of the 4th International Conference on Pediatric ENT (ed by Passali D). pp 3 9, Kugler Publications, The Hague, 1998. 
18) Yamagiwa M, Miyahara $Y$, Yamada $T$, et al : Nasal septum morphology vs cavity volume measured before and after nasal decongestion by means of acoustic rhinometer. 日鼻誌 $30: 127,1991$.

19) Pedersen OF, Berkowitz R, Yamagiwa M, et al : Nasal cavity dimensions in the newborn measured by acoustic reflections. Laryngoscope $104: 1023 \sim 1028,1994$.

20) Kano S, Pedersen OF and Sly PD : Nasal response to inhaled histamine measured by acoustic rhinometry in infants. Pediatr Pulmonol 17 : 312 319, 1994.

21) Djupesland PG and Lyholm B : Nasal airway dimensions in term neonates measured by continuous wide-band noise acoustic rhinometry. Acta Otolaryngol (Stockh) $117: 424$ 〜32, 1997.

22）山際幹和, 藤田健一郎：レミカット ${ }^{\circledR} の$ 鼻アレルギー鼻閉 に対する効果. 耳鼻臨床 $88: 263 \sim 269,1995$.

23）山際幹和, 藤田健一郎：アゼプチン®の鼻アレルギー鼻閉 に対する効果. 耳鼻臨床 $88: 381 \sim 388,1995$.

24）山際幹和, 徳力俊治 : フルナーゼ®点鼻液の抗アレルギー
性鼻閉効果. 耳鼻臨床 $89: 1283 \sim 1291,1996$.

25）山際幹和 : 小青竜湯 (TJ-19) の鼻アレルギー患者の鼻閉塞 に対する効果. 耳鼻臨床 補92:38４2, 1997.

26) Yamagiwa M, Miyahara $Y$ and Sakakura $Y$ : Nasal sensation of airflow and nasal geometry evaluated by acoustic rhinometry. Rhinology Up-to-date (ed by Passali D). pp 416 425, Indastria Grafica Romanasrl, Rome, 1994.

27）奥田 稔：6. 鼻アレルギー患者に接してーどら治療する か一 8. 抗アレルギー薬が多数開発されている. 鼻アレ ルギー．259２82頁，金原出版，東京， 1989.

28) Georgitis JW : The applicability of rhinomanometry in nonatopic children; comparison of three techniques. J Allergy $75: 614 \sim 620,1985$.

$$
\left(\begin{array}{l}
\text { 原稿受付 : 平成 } 9 \text { 年 } 10 \text { 月 } 23 \text { 日 } \\
\text { 原稿採択 : 平成 } 9 \text { 年 } 12 \text { 月 } 5 \text { 日 } \\
\text { 別刷請求先 : 山際幹和 } \\
\text { †5 } 515-8566 \text { 松阪市川井町字小望 } 102 \\
\text { 松阪中央総合病院耳鼻咽喉科 }
\end{array}\right)
$$

